\title{
Ekstraksi Ciri Sinyal EKG Aritmia Menggunakan Gelombang Singkat Diskrit
}

\author{
Ig R. Haryosuprobo ${ }^{1}$, Yohanes Sugiarto ${ }^{2}$, FX Suryadi ${ }^{3}$ \\ 1,2,Program Studi Teknik Mekatronika \\ ${ }^{3}$ Program Studi Teknik Perancangan Mekanik dan Mesin, \\ Politeknik ATMI Surakarta, Jl. Mojo No. 1 Surakarta 57145 \\ 1haryo_probo@yahoo.com, 리ohanessugiarto@yahoo.com, ${ }^{3} \mathrm{fx} \_$suryadi@atmi.ac.id
}

\begin{abstract}
Ringkasan
Angka kematian akibat penyakit jantung terutama penyakit jantung koroner tergolong sangat tinggi. Oleh karena itu, deteksi dan penanganan dini penyakit jantung ini dapat mencegah kerusakan permanen pada jaringan jantung.Sinyal EKG yang sama, yang diperoleh dari elektrokardiograf dapat diinterpretasikan berbeda-beda oleh para dokter. Hal itu disebabkan karena ragam penyakit jantung yang sangat banyak sehingga untuk mendiagnosa dengan tepat kelainan jantung tertentu seorang dokter harus memiliki keahlian khusus serta pengalaman yang memadai.

Pada penelitian ini akan diimplementasikan Ekstraksi Sinyal EKG Aritmia Menggunakan Gelombang Singkat Diskrit. Jenis pola jantung yang akan diteliti meliputi jantung Normal, Atrial Fibrilation, Ventricular Takikardia, Ventricular Fibrilation, serta Penyakit Jantung Koroner (PJK).

Tahap pertama penelitian adalah preprocessing yang meliputi penghapusan derau dan normalisasi sinyal. Tahap kedua adalah ekstraksi ciri menggunakan dekomposisi wavelet, sedangkan tahap selanjutnya adalah identifikasi sinyal EKG menggunakan JST backpropagation. Tahapan-tahapan tersebut berlaku untuk proses pelatihan maupun proses pengujian. Data penelitian terdiri atas data riil berupa grafik rekaman EKG dan data simulasi yang diambil dari MIT-BIH database.

Hasil simulasi menunjukkan akurasi jaringan sebesar 97\% dari total 187 data. Akurasi paling baik (100\%) dicapai pada EKG Atrial Fibrillation, sedangkan akurasi terendah $(79 \%)$ yaitu saat mengenali EKG Ventricular Fibrillation
\end{abstract}

Kata kunci: JST Backpropagation, EKG, ekstraksi ciri, wavelet

\section{Pendahuluan}

Sinyal EKG adalah sinyal listrik yang dihasilkan oleh aktifitas kelistrikan jantung. Kelainan dari fungsi jantung seseorang dapat dilihat dari rekaman sinyal EKG ini. Seorang ahli jantung menilai rekaman sinyal EKG dari bentuk gelombang, durasi, orientasi sinyal, dan irama sinyal. Penilaian ini relatif subyektif, tergantung dari keahlian dokter dan kondisi pasien. Seiring dengan kemajuan teknologi elektronika dan berkembangnya teknik-teknik pengolahan sinyal digital, banyak cara dikembangkan untuk mengenali kelainan jantung secara otomatis melalui pengenalan sinyal EKG[1][2][3]. Pengolahan sinyal EKG dapat dilakukan pada domain waktu, domain frekuensi atau domain wavelet. Pada penelitian ini dirancang sistem ekstraksi ciri 
sinyalEKG menggunakan gelombang singkat diskrit yang keluarannya akan dimasukkan ke JST backpropagation untuk diperoleh pengelompokan data berdasarkan pola energi sinyal masing-masing EKG.

\section{Dasar Teori}

Pada bagian ini, akan dijelaskan secara singkat mengenai elektrokardiograf dan sinyal EKG.

\subsection{Dasar Elektrokardiograf}

Elektrokardiograf adalah alat medis yang digunakan untuk merekam beda potensial bioelektrik di permukaan kulit yang dibangkitkan jantung dengan memasang elektroda rekam $(\mathrm{Ag} / \mathrm{AgCl})$ pada tempat tertentu di permukaan tubuh.

Sinyal EKG yang dihasilkan dari aktifitas listrik jantung dapat dilihat pada Gambar 1

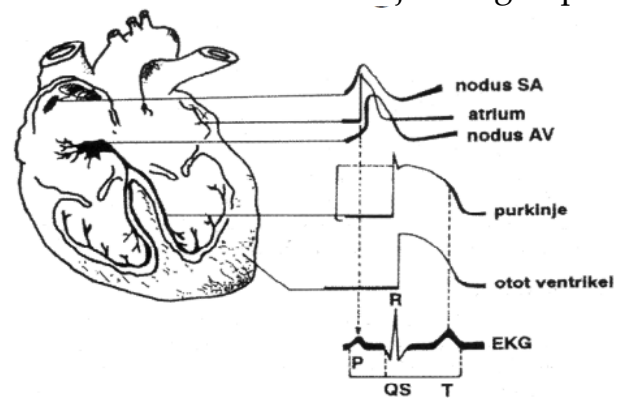

Gambar 1. Denyutan jantung menghasilkan grafik EKG[4]

Otot jantung terbentuk dari serabut - serabut otot yang bermuatan listrik, dikarenakan adanya aliran ion Natrium dari dan ke dalam sel. Akibat aliran ion Natrium ini, jantung mengalami siklus depolarisasi - repolarisasi secara kontinyu sehingga membentuk pola denyutan jantung.

Bioelektrik jantung dibangkitkan oleh sinoatrial node (SA node) dan atrioventricular node (AV node) kemudian menjalar melalui sel konduksi yang disebut berkas HIS atau serat purkinje selanjutnya mengalir ke seluruh bagian jantung sehingga membentuk kompleks sinyal EKG di permukaan tubuh seperti terlihat pada Gambar 2.

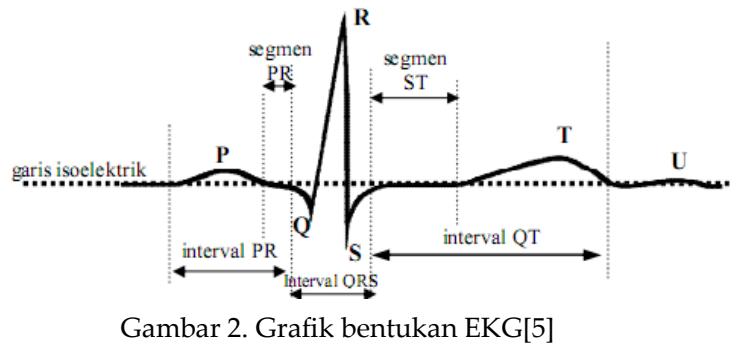

Tidak seluruh bagian rekaman EKG memiliki arti klinis dalam penafsirannya. Hanya bagian - bagian tertentu yang dipakai sebagai dasar penentuan suatu kondisi jantung.

Puncak P disebabkan karena depolarisasi atrium. Q, R, dan S membentuk bersama sama kompleks QRS, dan ini adalah hasil dari depolarisasi ventrikel. Setelah kompleks QRS, menyusul puncak T yang merupakan repolarisasi ventrikel. Peranan dari puncak U tidaklah begitu berperanan yang berkaitan dengan konsentrasi Kalsium dan Kalium dalam darah. Terjadinya puncak $\mathrm{U}$ ini kemungkinan disebabkan oleh repolarisasi dari 
serabut Purkinje. Repolarisasi atrium sering tidak jelas terlihat pada EKG disebabkan karena gelombang repolarisasi ini bersamaan dengan depolarisasi ventrikel (QRS) sehingga hilang ke dalamnya.

Terdapat 12 nilai yang memiliki arti klinis dari grafik keluaran EKG untuk menentukan kriteria kelainan, yaitu :
1. Irama
7. Interval Q
2. Frekuensi
8. Amplitudo R
3. Amplitudo gelombang $\mathrm{P}$
9. Segmen ST
4. Durasi gelombang P
10. Interval QTc
5. Interval PR
11. Amplitudo T
6. Interval QRS
12. Keteraturan

Gelombang EKG normal memiliki ciri-ciri sebagai berikut [6]:

1. Gelombang P mempunyai amplitudo kurang dari $0,3 \mathrm{mV}$ dan perioda kurang dari 0,11 detik.

2. Gelombang Q mempunyai amplitudo sebesar minus $25 \%$ dari amplitudo gekombang R.

3. Gelombang R mempunyai amplitudo maksimum $3 \mathrm{mV}$.

4. Gelombang $S$ merupakan defleksi negatif sesudah gelombang $\mathrm{R}$.

5. Kompleks QRS terdiri dari gelombang $Q$, $R$ dan $S$ yang memiliki perioda $0,06-0,10$ detik dengan perioda rata-rata 0,08 detik

Gelombang T mempunyai amplitudo minimum $0,1 \mathrm{mV}$.

\section{Metode Penelitian}

Algoritma secara keseluruhan yang meliputi akuisisi, pengumpulan data, prapemrosesan dan pemrosesan sinyal EKG dapat dilihat pada Gambar 3.

Data sinyal EKG yang digunakan dalam penelitian ini diperoleh dari dua kelompok . Kelompok pertama adalah data riil berupa data rekam EKG yang tercetak dalam kertas grafik dan diperoleh dari rumah sakit, akuisisi secara langsung dari pasien. Kelompok kedua berupa data simulasi yang diperoleh dari MIT-BIH database.

Data mentah dari rumah sakit maupun data hasil akuisisi sendiri merupakan data cetak citra analog 2-D. Sedangkan untuk proses analisis menggunakan komputer diperlukan data dalam bentuk digital. Scanning dilakukan untuk memperoleh data dalam bentuk digital. Scanning dilakukan pada resolusi $600 \mathrm{dpi}$.

Pra-pemrosesan terdiri atas proses segmentasi, transformasi kawasan spasial ke kawasan waktu, penyeragaman frekuensi cuplik, analisis spektral dan penghapusan derau. Analisis spektral EKG bertujuan untuk mengetahui kandungan frekuensi akibat interferensi jaringan listrik sebesar $60 / 50 \mathrm{~Hz}$. Penyeragaman frekuensi cuplik sebesar 300 $\mathrm{Hz}$ agar dapat mengambil frekuensi maksimum EKG yang direkomendasikan oleh organisasi AHA, ANSI, dan AAMI, yaitu $150 \mathrm{~Hz}$ dalam rentang 0,05-150 Hz.

Setelah diperoleh data sinyal EKG dalam kawasan waktu 1-D hasil proses transformasi, dilakukan proses berikutnya yaitu penghapusan derau akibat interferensi jaringan listrik menggunakan filter takik $60 \mathrm{~Hz}$ untuk data yang berasal dari MIT-BIH database dan filter takik $50 \mathrm{~Hz}$ untuk data riil. Proses berikutnya adalah menghilangkan baseline wander menggunakan transformasi wavelet diskrit. 


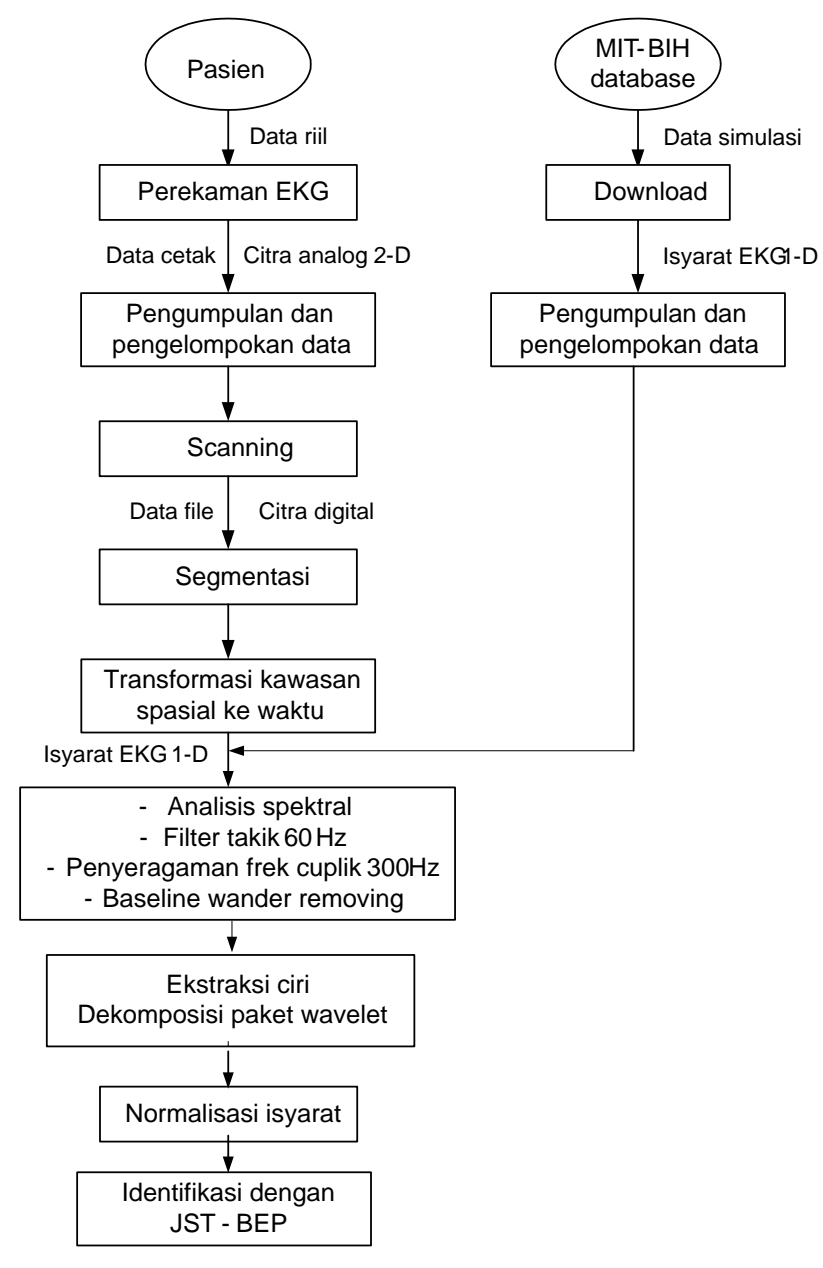

Gambar 3. Diagram alir metode penelitian

Tahap pemrosesan terdiri atas proses ekstraksi ciri dan identifikasi. Proses ekstraksi ciri dilakukan untuk memperoleh ciri-ciri khusus masing-masing kasus serta memberikan pola pada masing-masing kasus tersebut. Proses ini dilakukan dengan metoda dekomposisi wavelet sampai 6 level dengan menggunakan Symlet 8 sebagai mother wavelet. Hasil dekomposisi ini berupa sub-band $\mathrm{D}_{1}$ sampai $\mathrm{D}_{6}$ sebagai detil dan A6 sebagai aproksimasi. Dari hasil dekomposisi tersebut dihitung energi rerata sinyal masing-masing sub-band yang akan menjadi featuresinyal EKG yang diamati. Hasilnya berupa matriks $7 \times 1$.

Hasil ekstraksi ciri berupa matriks $7 \times 1$ tersebut selanjutnya menjadi masukan bagi JST Back Error Propagation untuk dilakukan identifikasi menurut pola masing-masing.

\subsection{Dekomposisi Wavelet}

Pada dekomposisi paket wavelet sinyal dibagi menjadi komponen aproksimasi dan detail. Komponenaproksimasi kemudian dibagi lagi menjadi komponen aproksimasi dan detail, begitu seterusnya sampai dengan level yang diinginkan [1]. 


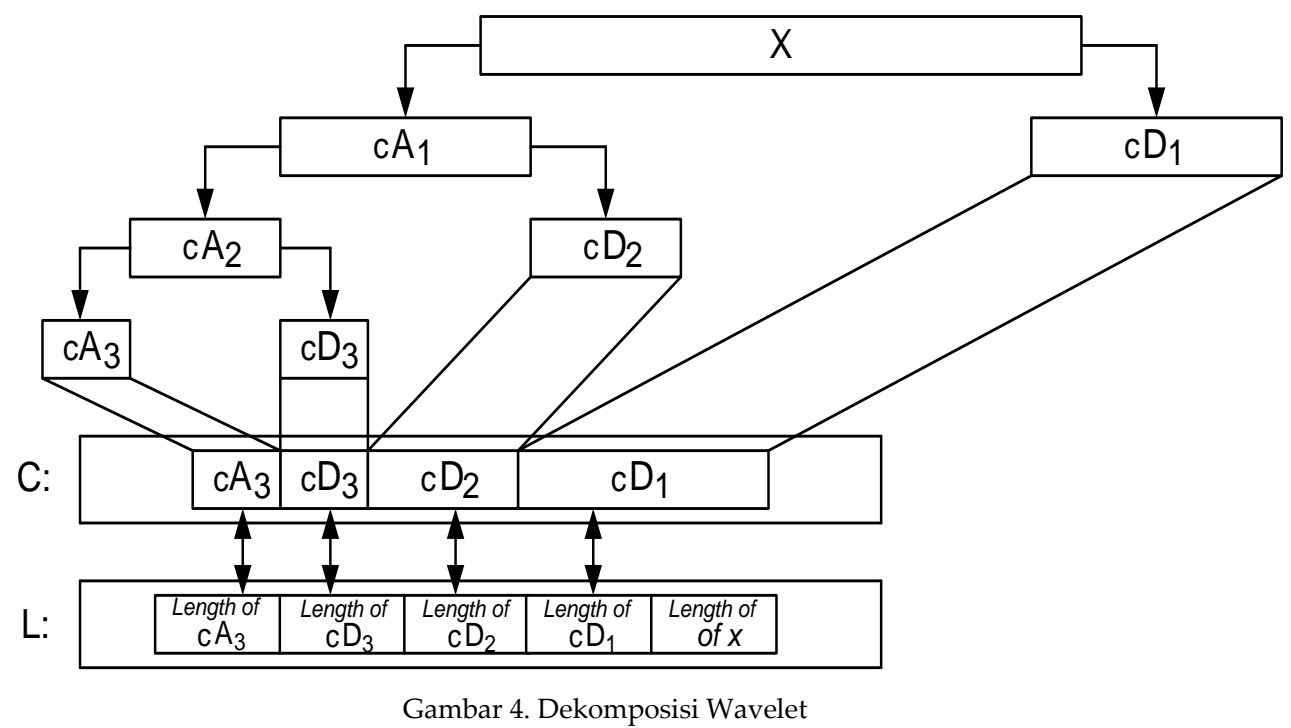

Secara matematis dekomposisi wavelet 3 tingkat dapat dituliskan[4]:

$$
\begin{gathered}
\quad X=c A_{1}+c D_{1} \\
=c A_{2}+c D_{2}+c D_{1} \\
=c A_{3}+c D_{3}+c D_{2}+c D_{1}
\end{gathered}
$$

Komponen $c A_{1}$ dan $c D_{1}$ didapat lewat operasi seperti pada Gambar 5.

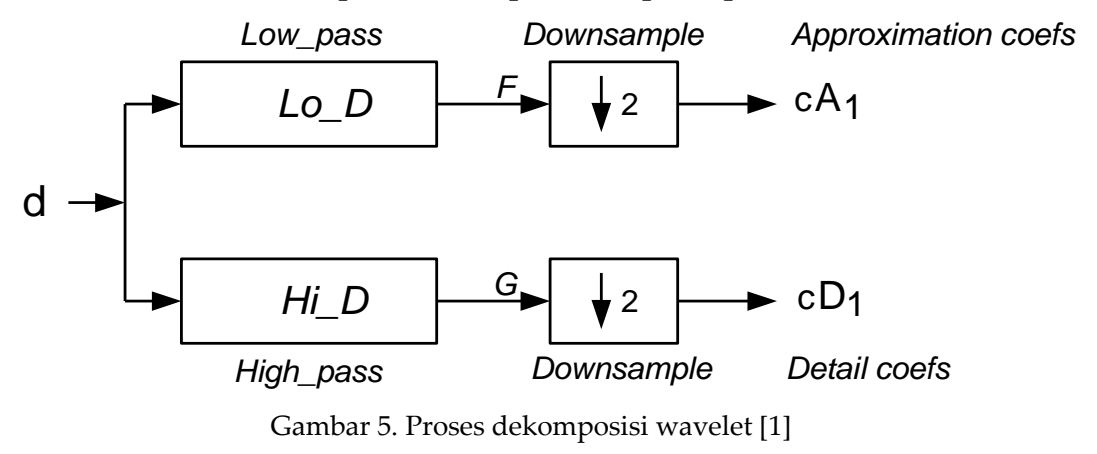

Dengan mendekomposisi sinyal EKG, akan diperoleh kompoden detil $\left(D_{1}, D_{2}, D_{3}, D_{4}, D_{5}\right.$, dan $\left.D_{6}\right)$ serta aproksimasi $\left(A_{6}\right)$. Masing-masing detil di tiap tingkat dan aproksimasi pada tingkat terakhir (tingkat 6 ) dihitung energi dekomposisi reratanya sebagai ekstraksi ciri sinyal EKG.Energi dekomposisi rerata detil tiap sub-band EDi dihitung dengan persamaan:

$$
E_{D i}=\sum\left(D_{i}(k) / N D_{i}\right.
$$

dengan $N D_{i}$ adalah jumlah cuplikan $D_{i}, k=1,2, \ldots, N D_{i}$ dan $i=1,2, \ldots, 6$.

Energi dekomposisi rerata aproksimasi $A_{6}\left(\mathrm{E}_{\mathrm{A}}\right)$ dihitung dengan persamaan:

$$
E_{A 6}=\sum\left(A_{6}(k) / N A_{6},\right.
$$

dengan $N A_{6}$ adalah jumlah cuplikan $A_{6}$ dan $k=1,2, \ldots, N A_{6}$

Ilustrasi dekomposisi sinyal EKG 6 tingkat dengan frekuensi cuplik $300 \mathrm{~Hz}$ dapat dilihat pada Gambar 6 berikut: 


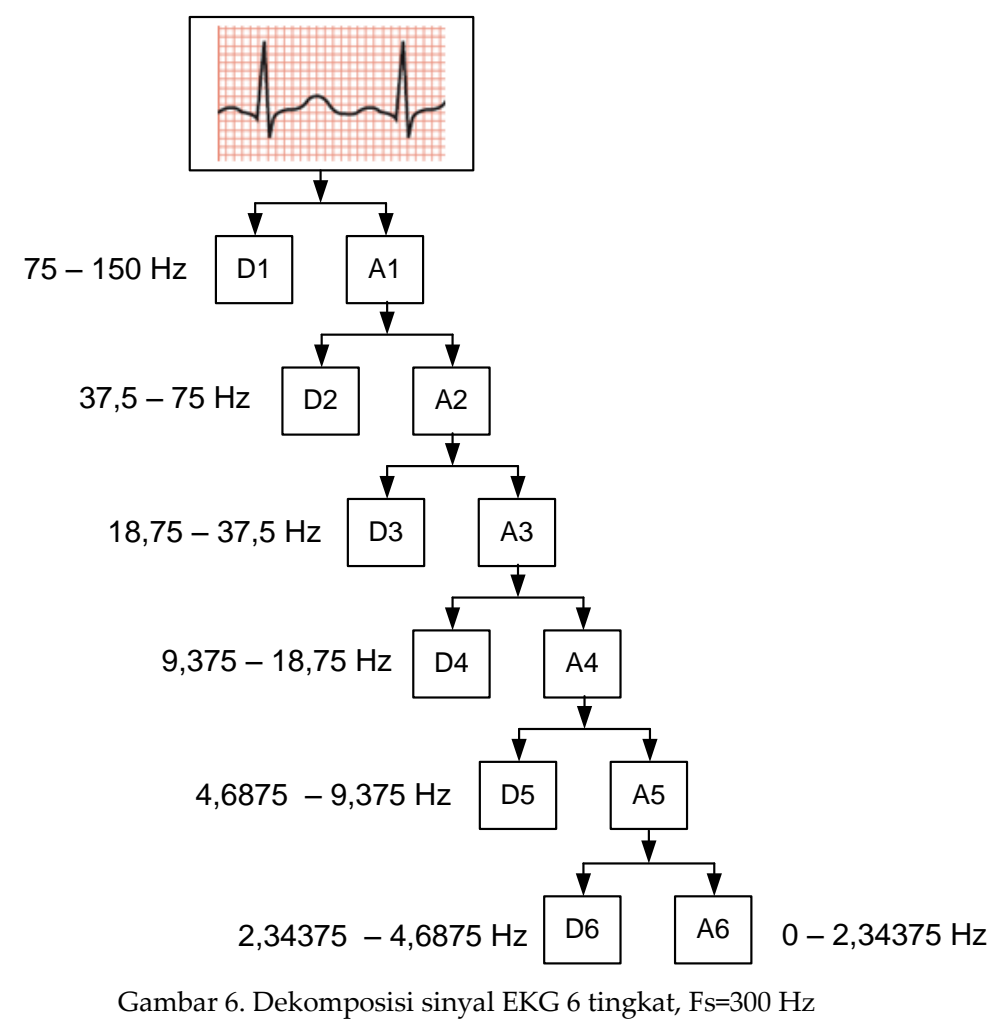

Masing-masing energi rerata dekomposisi selanjutnya dinormalisasi sehingga rentang nilainya antara 0 dan 1 dengan persamaan berikut

$$
E N_{j}=E_{D i} / \max \left(E_{D i}, E_{A 6}\right), \quad j=1,2,3, \ldots, 7
$$

di mana:

$E N_{j}=$ Energi rerata normalisasi pada dekomposisi ke- $j$

$E_{D i}=$ Energi rerata sinyal detil ke- $i(i=1,2,3, \ldots, 6)$

$E_{A 6}=$ Energi rerata sinyal aproksimasi $A_{6}$

Energi rerata yang dinormalisasi dari tiap dekomposisi ini selanjutnya dipakai menjadi input jaringan syaraf tiruan back error propagation untuk identifikasi sinyal EKG.

\subsection{Jaringan Syaraf Tiruan Back Propagation}

Jaringan syaraf yang banyak digunakan adalah Back propagation Neural Net. Dari beberapa perkiraan, hampir $90 \%$ aplikasi berbasis JST menerapkan metode backpropagation. Jaringan ini juga dikenal dengan sebutan Feedforward Neural Network [3].

Arsitektur rancangan backpropagation ditunjukkan pada Gambar 7 


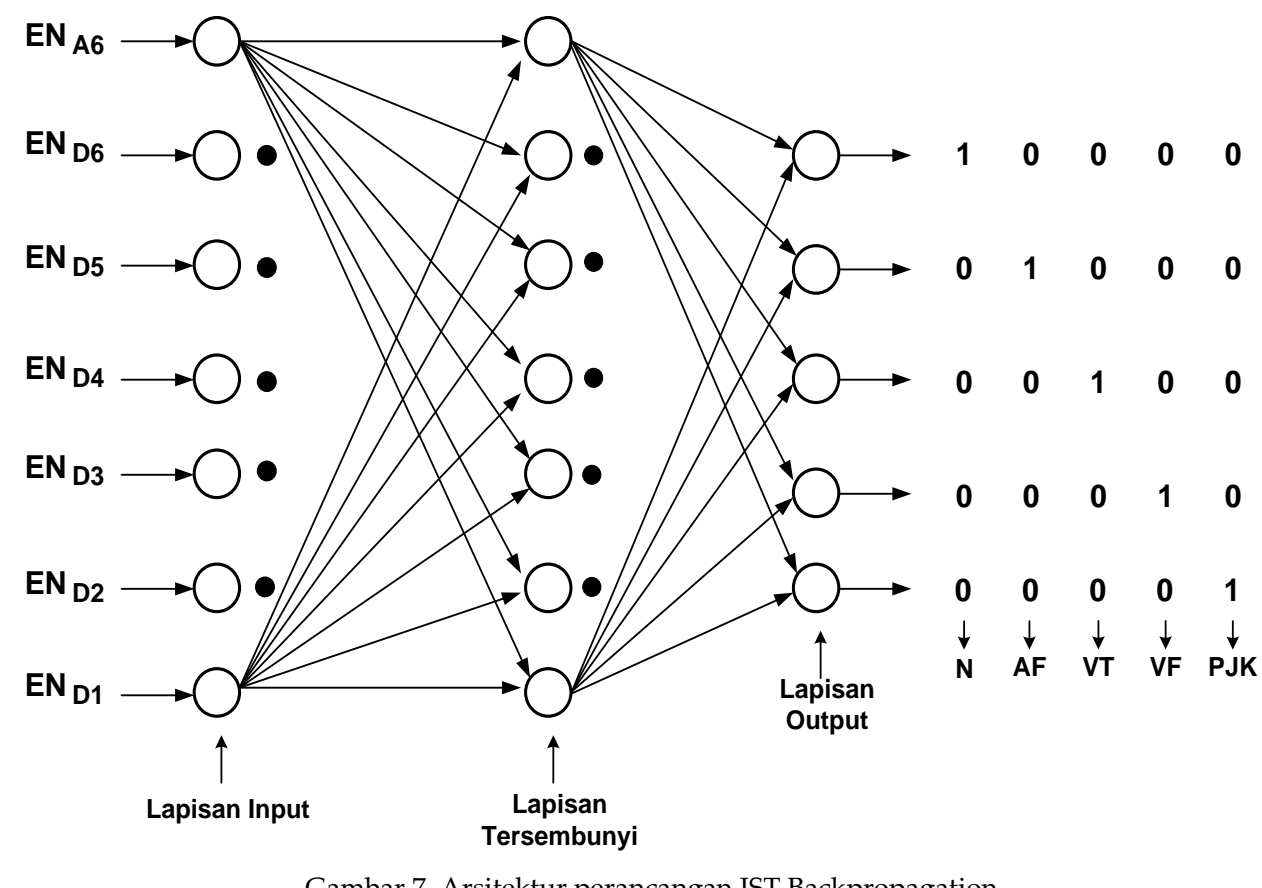

Dalam penelitian ini dirancang jaringan syaraf seperti Gambar 7, dengan 7 simpul lapis masukan (input layer) karena mapping masukan berupa matriks $7 \times 1$ untuk tiap - tiap klasifikasi. Untuk jumlah simpul lapis tersembunyi (hidden layer) dirancang sejumlah 7 , menurut Shibata dan Ikeda [12], jumlah neuron pada lapisan tersembunyi $\mathrm{N}_{\mathrm{h}}$ pada JST back error propagation dapat diperkirakan dari jumlah neuron input $N_{i}$ dan jumlah neuron output $N_{o}$ menurut persamaan berikut:

$$
N_{h}=\sqrt{N_{i} N_{o}}
$$

Kemudian lapis keluaran (output layer) berjumlah lima buah simpul (sejumlah kelas data sinyal EKG yang diteliti).

Dalam simpul input layer tidak terdapat proses perhitungan apapun hanya melewatkan masukan saja, sedangkan pada simpul hidden layer dan output layer terdapat perhitungan penjumlahan bobot dan aktivasi.

Fungsi aktivasi (activation function) diperlukan jaringan untuk membuat ketidaklinieran keluaran simpul sehingga simpul tidak hanya menghasilkan keluaran sebagaimana masukannya. Fungsi lainnya adalah untuk membatasi nilai keluaran pada rentang tertentu.

Fungsi yang umum diterapkan dalam JST back propagation adalah fungsi sigmoid binary, yaitu :

$$
F(x)=\frac{1}{1+\mathrm{e}^{-\mathrm{x}}}
$$

dengan turunan,

$$
f^{\prime}(x)=F(x)[1-F(x)]
$$

Grafik fungsi sigmoid terlihat pada Gambar 8 berikut : 


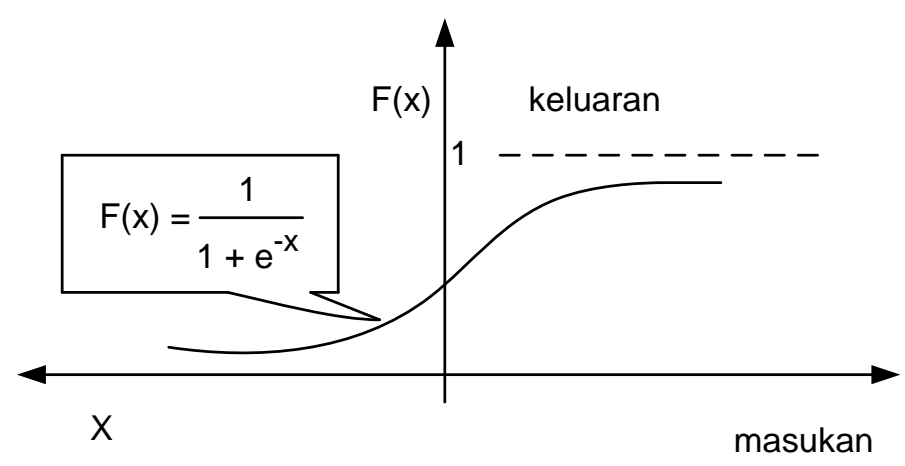

Gambar. 8 Grafik fungsi sigmoid

Terlihat pada grafik diatas dengan adanya fungsi aktivasi sigmoid maka keluaran simpul akan tidak linier tetapi dalam rentang antara 0 dan 1.

Pada sistem jaringan syaraf tiruan terdapat 2 macam sistem belajar, yaitu supervised (terbimbing) dan unsupervised (tidak terbimbing).

Dalam perancangan penelitian ini diterapkan metode belajar terbimbing karena target keluarannya sudah ditentukan terlebih dahulu.

Sedangkan target keluaran menunjukkan lima pola sinyal EKG yang telah teridentifikasi. Dalam penelitian ini jaringan syaraf difungsikan sebagai pengklasifikasi sinyal EKG yang menggambarkan kondisi jantung. Berikut adalah 5 kondisi jantung beserta target keluaran yang disajikan pada tabel 1 :

TABEL 1

KELUARAN TARGET IDENTIFIKASI

\begin{tabular}{|c|c|c|c|c|c|c|}
\hline No & \multirow{2}{*}{$\begin{array}{c}\text { Kondisi Jantung } \\
\text { Normal }\end{array}$} & \multicolumn{5}{|c|}{$\begin{array}{c}\text { Target Keluarar } \\
y_{1} y_{2} y_{3} y_{4} y_{5}\end{array}$} \\
\hline 1 & & 1 & 0 & 0 & & 0 \\
\hline 2 & Atrial Fibrillation & 0 & 1 & 0 & & 0 \\
\hline 3 & Ventricular Tachycardia & 0 & 0 & 1 & 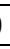 & 0 \\
\hline 4 & Ventricular Fibrillation & 0 & 0 & 0 & & 0 \\
\hline 5 & Penyakit Jantung Koroner & 0 & 0 & 0 & 0 & 1 \\
\hline
\end{tabular}

Algoritma backpropagation meliputi tiga tahap prosedur, yaitu :

- Prosedur feedforward

- Perhitungan serta perambatan balik kesalahan

- Penyesuaian bobot.

Sebelum proses pelatihan, terlebih dahulu ditentukan bobot-bobot awal secara acak dan toleransi kesalahan minimum $(\varepsilon)$. Bobot-bobot awal ini nantinya diinisialisasi dan digunakan pada proses feedforward awal, sedangkan proses feedforward selanjutnya menggunakan bobot-bobot yang telah mengalami perbaikan. Toleransi kesalahan minimum $(\varepsilon)$ berfungsi sebagai pembatas berulangnya proses iterasi dalam suatu pelatihan. Proses pelatihan akan terus berulang hingga diperoleh koreksi kesalahan yang sama dengan/lebih kecil dari toleransi kesalahan minimum.

Algoritma feedforward diuraikan dalam langkah-langkah atau alur prosedur sebagai berikut [10] : 
Langkah 1 :

Setiap unit masukan $\left(x_{n}, n=1, \ldots, n\right)$ menerima sinyal-sinyal masukan $\mathrm{Xn}$ dan mengirimkan sinyal-sinyal ini ke unit-unit selanjutnya (unit-unit tersembunyi).

Langkah2 :

Setiap unit tersembunyi $(i h, h=1, \ldots, h)$ menjumlahkan sinyal-sinyal terbobotnya:

$$
i \_i n_{h}=\theta_{h n}+\sum_{\mathrm{n}} \mathrm{Xn}_{\mathrm{n}} w_{h n}
$$

Kemudian menerapkan fungsi aktivasinya untuk menghitung sinyal keluarannya:

$$
i_{h}=f\left(i_{-} i n_{h}\right)
$$

lalu mengirimkannya pada semua unit lapis lapis keluaran.

Langkah 3 :

Setiap unit keluaran $(o k, k=1, \ldots, k)$ menjumlahkan sinyal masukan terbobotnya :

$$
o \_i \eta_{k}=\theta_{k h}+\sum_{\mathrm{h}} i_{h} w_{k h}
$$

Kemudian menerapkan fungsi aktivasi untuk menghitung sinyal keluarannya :

$$
o k=f\left(o_{-} i n k\right)
$$

Setelah sinyal keluaran didapatkan maka akan dimulai tahapan prosedur penghitungan kesalahan dan perambatan balik nilai kesalahan ke lapis tersembunyi lalu ke lapis keluaran sebagaimana dijelaskan dalam langkah berikut:

Langkah 4 :

Pada setiap unit keluaran $(o k, k=1, \ldots, k)$ menerima sebuah pola keluaran target yang berhubungan dengan pola masukan pelatihan, untuk menghitung informasi kesalahannya,

$$
\delta_{k}=\left(t_{k}-o_{k}\right) f\left(o_{k}\right)
$$

Lalu menghitung besar koreksi bobotnya (untuk memperbaiki wkh) :

$$
\Delta w_{k h}=\eta \delta \delta_{k} h
$$

Selanjutnya menghitung besar koreksi biasnya

$$
\Delta \theta_{k h}=\eta \delta k
$$

dan mengirimkan $\delta_{k}$ ke unit-unit lapis tersembunyi.

Langkah 5 :

Pada setiap unit tersembunyi $(i h, h=1, \ldots, h)$ jumlahkan masukan deltanya (dari unit-unit lapis keluaran):

$$
\Delta_{-} i \eta_{h}=\sum_{\mathrm{k}} \delta k w_{k h}
$$

Kemudian hasil ini akan digunakan untuk menghitung besar informasi kesalahannya,

$$
\delta_{h}=\delta \_i{ }_{h} f^{\prime}\left(i_{h}\right)
$$


Lalu menghitung besar koreksi bobotnya (untuk memperbaiki $w_{h n}$ ),

$$
\Delta w_{h n}=\eta \delta_{h} x_{n}
$$

Dan menghitung koreksi biasnya (untuk memperbaiki $\theta_{h n}$ ),

$$
\Delta \theta_{h n}=\eta \delta_{h}
$$

Prosedur selanjutnya adalah proses perbaikan bobot dan bias dari unit input dan unit tersembunyi, diuraikan dalam langkah-langkah berikut :

Langkah 6 :

Masing-masing unit keluaran $(o k, k=1, . ., k)$ diperbaiki bobot dan biasnya

$$
\begin{aligned}
& w_{k h}(\text { baru })=w_{k h}(\text { lama })+\Delta w_{k h} \\
& \theta_{k h}(\text { baru })=\theta_{k h}(\text { lama })+\Delta \theta_{k h}
\end{aligned}
$$

Langkah 7 :

Masing-masing unit tersembunyi $(i h, h=1, \ldots, h)$ diperbaiki bobot dan biasnya

$$
\begin{aligned}
& w_{h n}(\text { baru })=w_{h n}(\text { lama })+\Delta w_{h n} \\
& \theta_{h n}(\text { baru })=\theta_{h n}(\text { lama })+\Delta \theta_{h n}
\end{aligned}
$$

Langkah 8 :

Proses berhenti pada saat koreksi kesalahan mencapai minimum.

Epoch (jangka waktu) adalah satu set putaran vektor-vektor pelatihan sebuah JST back propagation. Dalam algoritma ini dilakukan perbaikan bobot setelah masing-masing pola pelatihan disajikan. Setelah pelatihan selesai, bobot-bobot yang telah mengalami perbaikan tersebut disimpan dalam suatu file.

\section{Hasil dan Analisis}

Perubahan tanda yang khas pada sinyal EKG penyakit jantung koroner adalah dijumpainya elevasi ST segmen lebih dari $1 \mathrm{~mm}$ pada limb leads dan lebih dari $2 \mathrm{~mm}$ pada lead dada, depresi ST segmen , T inversi atau keduanya, dan pada tingkatan yang lebih fatal adalah kematian jaringan jantung yang ditandai dengan gelombang $Q$ patologi [11]. Total data yang digunakan pada penelitian ini sebanyak 187 data. Gambar 9, 10, dan 11 adalah contoh sinyal EKG setelah melalui proses pre-prosesing.

Akurasi JST back propagation berdasar dua hal, yaitu akurasi sistem yang dituntut mampu mengenali pola yang telah diajarkan maupun pola mirip dan keakuratan data saat pembelajaran awal pola yang dikenalkan. 


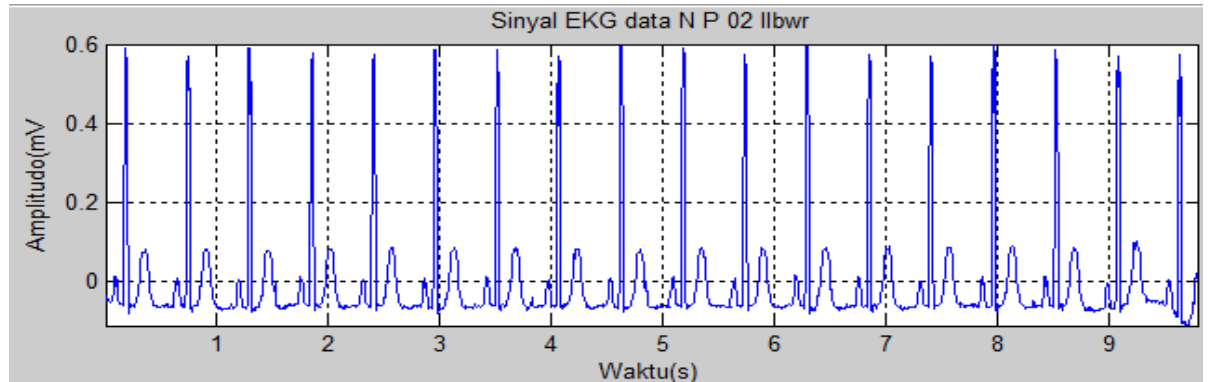

(a)

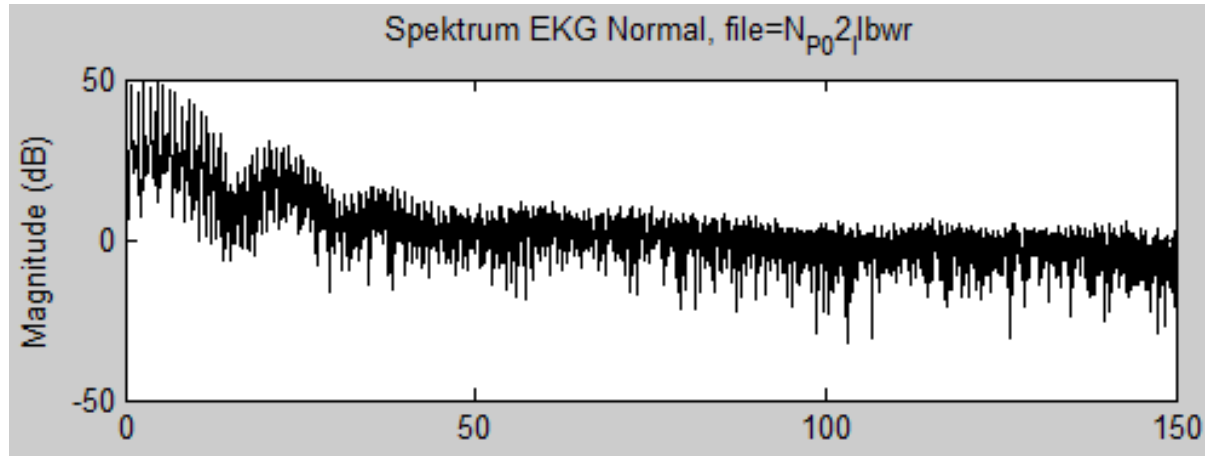

(b)

Gbr. 9 (a) Sinyal EKG normal (b) Spektrum frekuensi

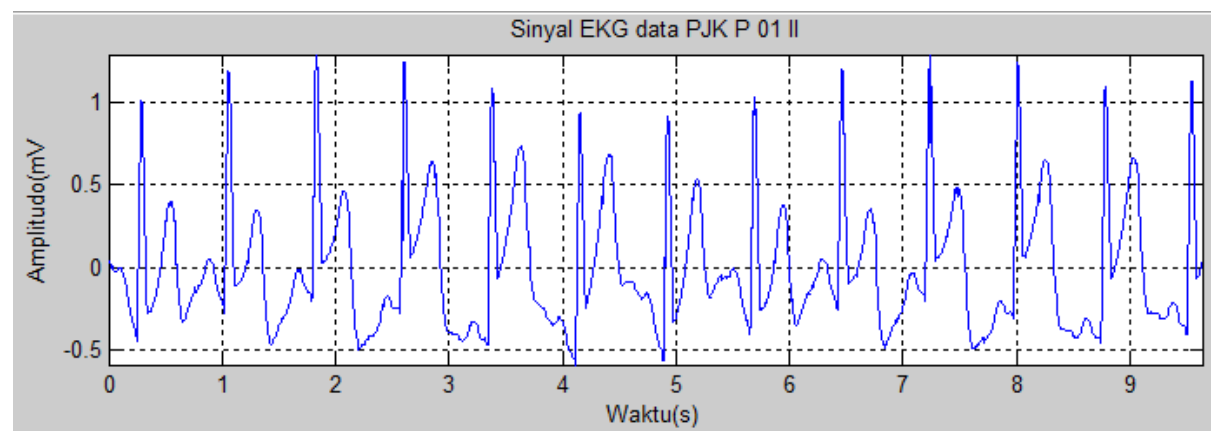

(a)

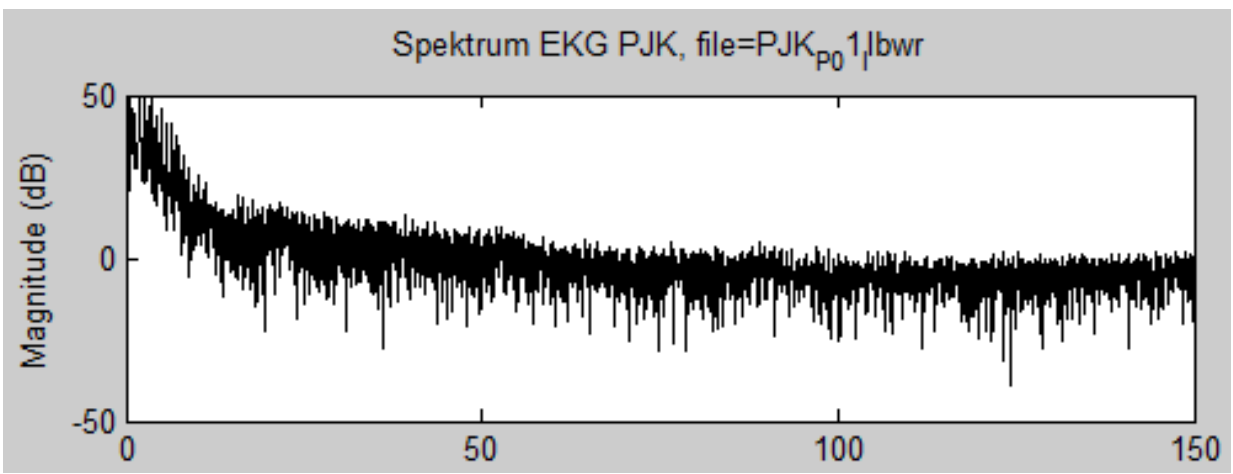

(b)

Gbr. 10 (a) Penyakit Jantung Koroner (b) Spektrum frekuensi 


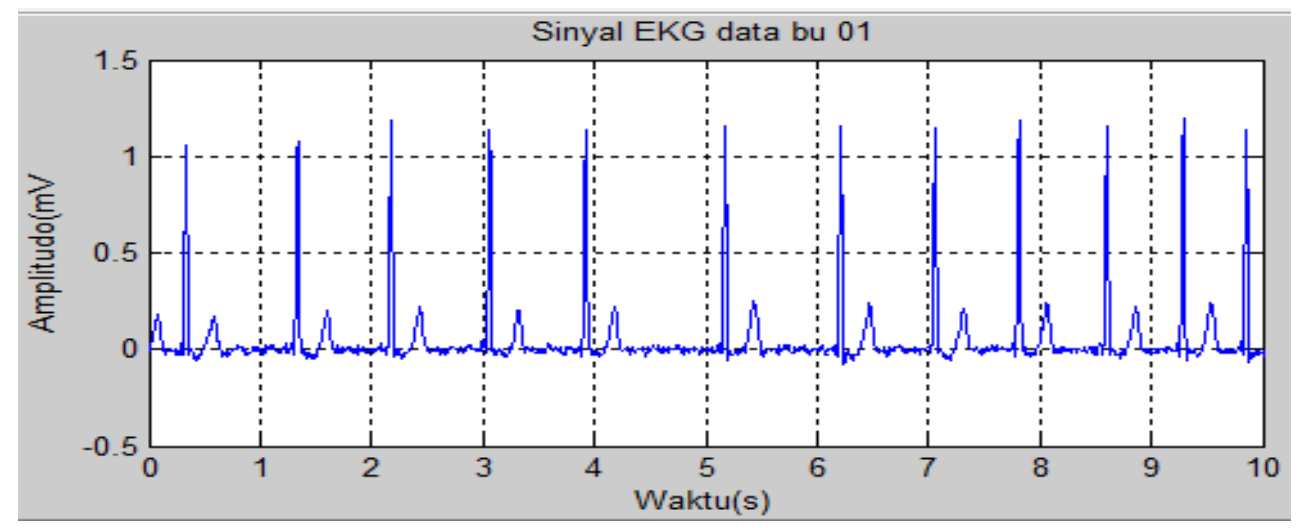

(a)

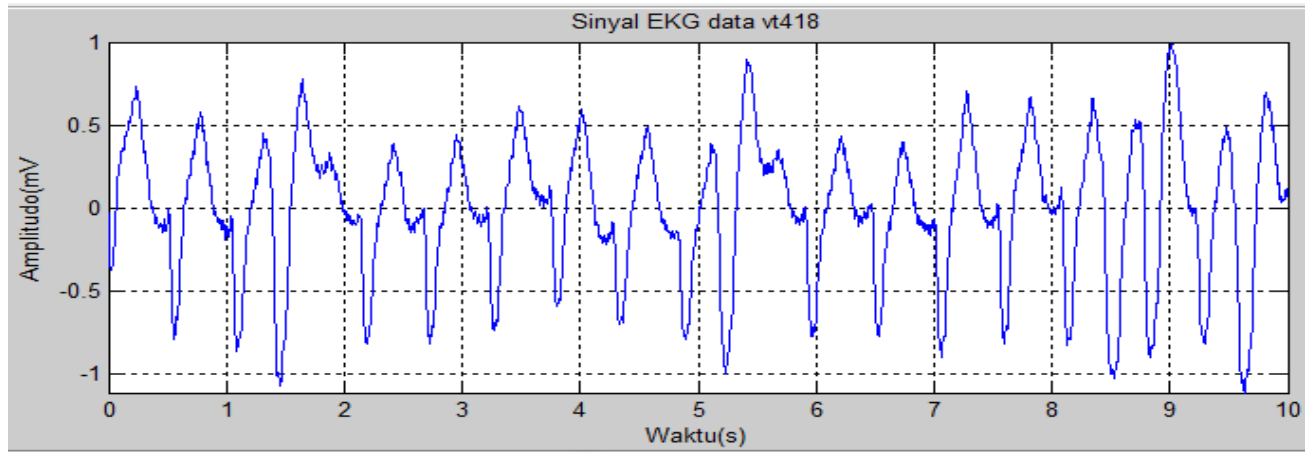

(b)

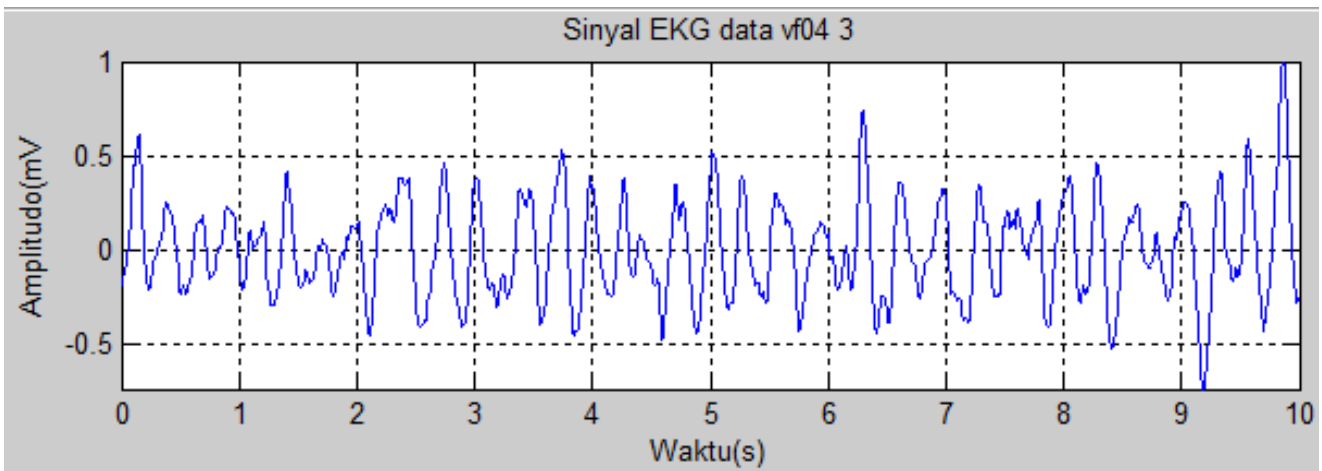

(c)

Gbr. 11 Sinyal EKG sample yang diambil dari Physionet

(a) Atrial Fibrillation (b) Ventricular Takokardia (c) Ventricular Fibrillation

Gambar 9, 10, dan 11 merupakan sinyal EKG yang telah mengalami tahap prapemrosesan seperti reduksi derau interferensi jaringan listrik dan derau beseline wander serta penyeragaman frekuensi cuplik $300 \mathrm{~Hz}$. Hasil reduksi derau akibat interferensi jaringan listrik $60 \mathrm{~Hz}$ dan harmonisanya $(120 \mathrm{~Hz}, 180 \mathrm{~Hz}$, dst) dapat dilihat pada Gambar 12 berikut 


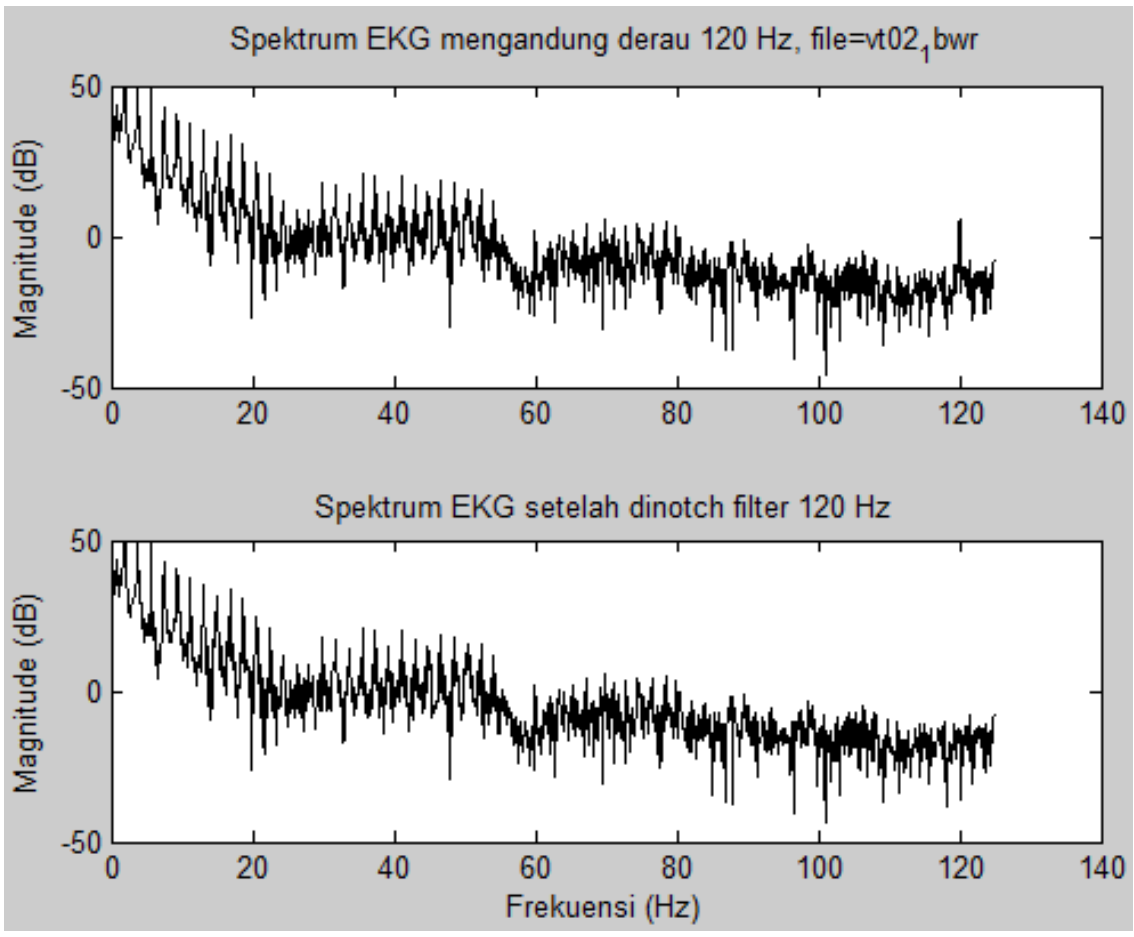

Gbr. 12 Reduksi derau akibat interferensi jaringan listrik $60 \mathrm{~Hz}$ dan harmonisanya. Sebelum difilter (atas) setelah difilter (bawah)

Ekstraksi ciri diperoleh dengan mererata pola ekstraksi ciri sinyal EKG individu dalam satu kelompok yang memiliki pola yang mirip. Dalam penelitian ini ditemukan untuk masing-masing kelompok pola, ada lima pola ciri yang mirip. Sehingga akan diperoleh untuk masing-masing kelompok pola sinyal EKG adalah lima pola. Hal ini dilakukan karena tidak berimbangnya jumlah sinyal pada masing-masing pola, dimana sinyal EKG jenis Normal memiliki sinyal individu paling banyak yaitu 104 data, sedangkan PJK sebanyak 41 data, dan untuk masing-masing sinyal AF, VT, dan VF sebanyak 14 data. Dengan mererata pola ekstraksi ciri, masing-masing jenis EKG memiliki jumlah data pelatihan yang sama yaitu lima pola hasil ekstraksi ciri tersebut. Berikut adalah hasil ekstraksi ciri kelima jenis sinyal EKG. 


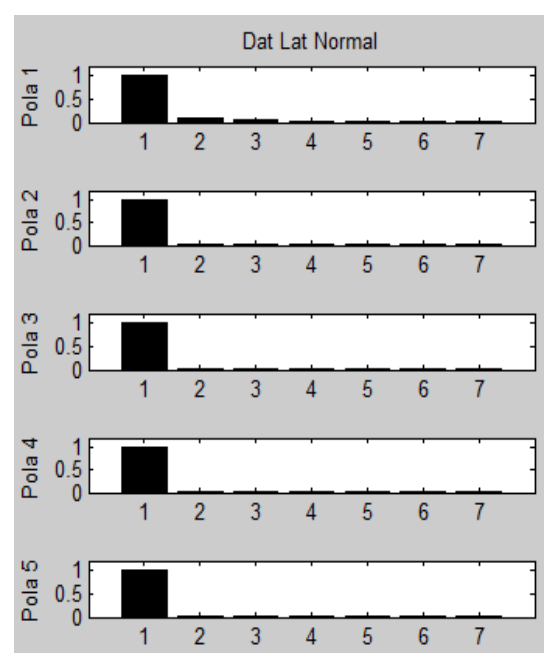

(a)

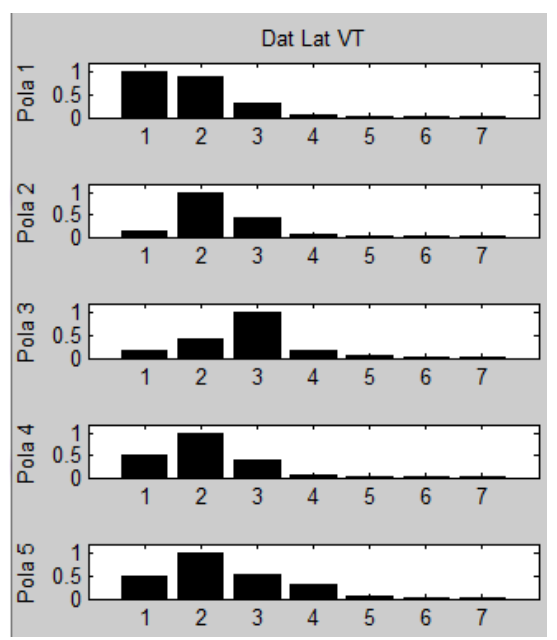

(c)

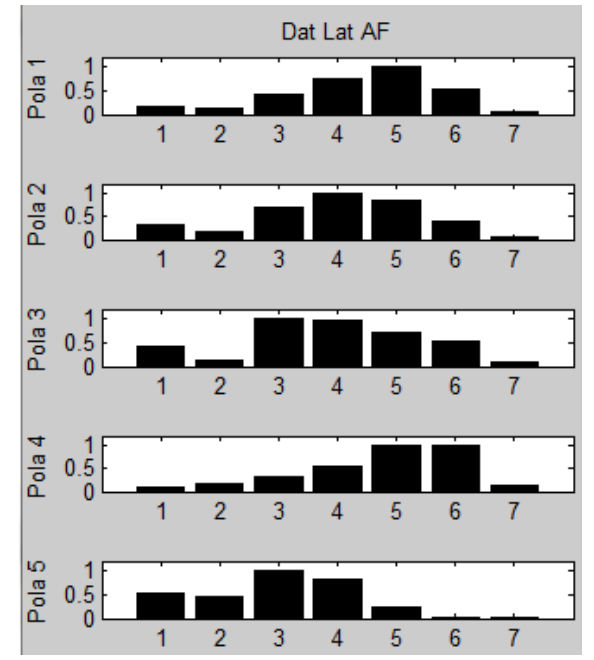

(b)

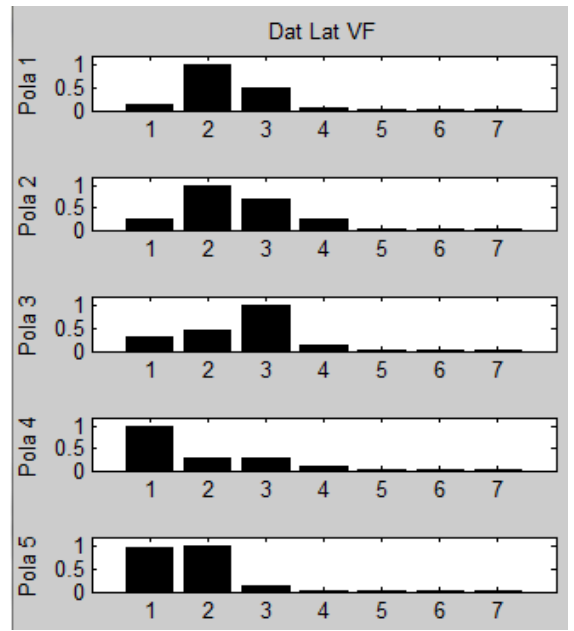

(d)

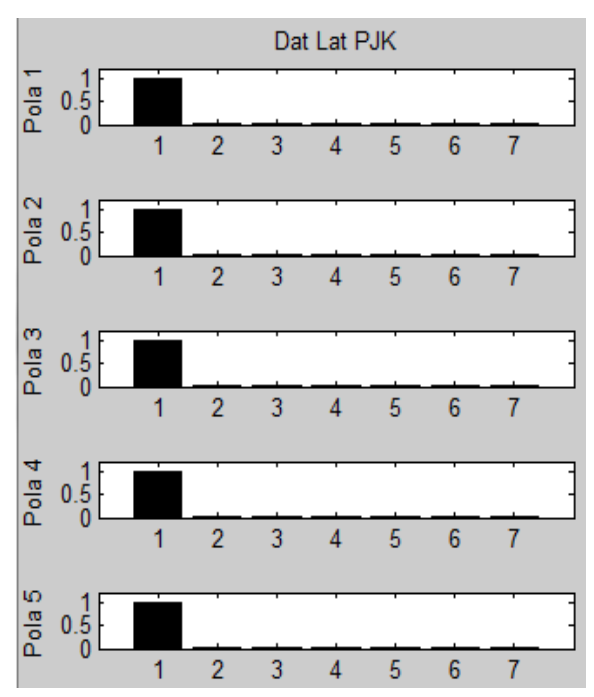

(e)

Gbr 13 Data latih jaringan syaraf tiruan (a) N, (b) AF, (c) VT. (d) VF, (e) PJK 
TABEL 2 HASIL IDENTIFIKASI SINYAL EKG

\begin{tabular}{|c|c|c|c|c|c|}
\hline No & Jenis EKG & Dikenali & Tidak dikenali & Jumlah & $\begin{array}{c}\text { Presentasi akurasi } \\
(\%)\end{array}$ \\
\hline 1 & Normal & 103 & 1 & 104 & $99 \%$ \\
\hline 2 & AF & 14 & 0 & 14 & $100 \%$ \\
\hline 3 & VT & 13 & 1 & 14 & $93 \%$ \\
\hline 4 & VF & 11 & 3 & 41 & $79 \%$ \\
\hline 5 & PJK & 40 & 1 & & $98 \%$ \\
\hline
\end{tabular}

Dari Tabel 2 dapat diketahui nilai persentase akurasi jaringan syaraf tiruan yang dibangun untuk mengenali semua jenis sinyal EKG sebesar 97\%. Persentase akurasi tertinggi jaringan, ketika mengenali EKG jenis Atrial Fibrillation (100\%) dan persentase terendah jaringan yaitu ketika mengenali Ventricular Fibrillation (79 \%). Hal tersebut menunjukkan bahwa sistem secara keseluruhan mampu mengidentifikasi sinyal EKG dari kelima jenis kondisi jantung berdasarkan ekstraksi ciri energi rerata hasil dekomposisi wavelet Symlet orde 8 (sym8) 6 tingkat. Namun demikian dalam mengenali jenis EKG VF, sistem masih harus diperbaiki lagi, misalnya dengan mengubah-ubah jumlah neuron dalan lapisan tersembunyi karena memang jenis sinyal EKG VF memiliki pola yang beragam dan bersifat acak.

\section{Kesimpulan dan Saran}

\subsection{Kesimpulan}

Dari data hasil dan analisis dalam penelitian ini, maka dapat ditarik beberapa kesimpulan sebagai berikut:

1. Keberhasilan secara keseluruhan sistem dalam mengenali pola sinyal EKG sangat dipengaruhi oleh pra-pemrosesan. Karakteristik sinyal EKG penting untuk diketahui sebelum dilakukan proses ekstraksi ciri dan identifikasi, sehingga perlakuan secara tepat terhadap sinyal tersebut dapat dilakukan untuk menjamin bahwa sinyal EKG yang akan dianalisis merupakan representasi sinyal aslinya. Pada penelitian ini, prapemrosesan yang dilakukan meliputi segmentasi dan transformasi data spasial ke data satu dimensi untuk semua data yang berasal dari kertas rekaman EKG, penapisan derau akibat jaringan listrik $60 / 50 \mathrm{~Hz}$ menggunakan filter takik IIR orde 2, penyeragaman frekuensi cuplik menjadi $300 \mathrm{~Hz}$ supaya rentang frekuensi masingmasing sub-band menjadi seragam, kemidian terakhir adalah menghilangkan derau baseline wander menggunakan metoda dekomposisi paket wavelet hingga 11 tingkat.

2. Energi rerata hasil dekomposisi sinyal EKG 6 tingkat yang diperoleh dari transformasi wavelet Symlet 8 dapat digunakan sebagai akstraksi ciri sinyal EKG jenis Normal, Atrial Fibrillation,Ventricular Tachycardia, Ventricular Fibrillation, dan Penyakit Jantung Koroner.

3. Jaringan syaraf tiruan BEP mampu mengidentifikasi 5 jenis sinyal EKG (Normal, AF, VT, VF, dan PJK) berdasarkan energi rerata hasil dekomposisi paket wavelet sampai 6 tingkat. Laju pembelajaran (learning rate) 0,1 dan momentum 0,7 paling optimal untuk mengenali pola EKG yang dilatihkan. Struktur jaringan yang dibuat terdiri atas 7 neuron input, 7 neuron pada lapisan tersembunyi, dan 5 neuron output. Nilai persentase akurasi jaringan syaraf tiruan yang dibangun untuk mengenali semua jenis sinyal EKG sebesar 97\%. Persentase akurasi tertinggi jaringan, ketika mengenali EKG jenis AF (100\%) dan persentase terendah jaringan yaitu ketika mengenali VF (79 $\%)$. 


\subsection{Saran}

Sebagai pengembangan untuk penelitian berikutnya maka berikut adalah saransaran yang dapat dipakai sebagai acuan

1. Untuk meningkatkan presentase akurasi jaringan dalam mengenali setiap pola sinyal EKG, perlu dicoba untuk memberikan variasi jumlah neuron pada lapisan tersembunyi sehinggadiperoleh jumlah yang optimal dalam mengenali pola sinyal EKG.

2. Perlu dicoba Multi Layer Perceptron (MLP) menggunakan algoritma Levenberg Marquardt yang merupakan salah satu metode optimasi untuk menyelesaikan masalah kuadrat terkecil yang didasarkan pada metode Gauss-Newton sebagai pembanding dengan algoritma back error propagation.

3. Hasil penelitian ini dapat dikembangkan menjadi sistem yang dapat dihubungkan dengan elektrokardiograf sehingga dapat melakukan analisis dan identifikasi secara online, atau dikembangkan menjadi sistem tertanam (embedded system).

\section{Daftar Pustaka}

[1] A. Rizal, V. Suryani, “Pengenalan ECG menggunakan dekomposisi paket wavelet kmeans clustering," Proceeding SNATI 2008, Universitas Indonesia, Yogyakarta, 2008.

[2] G. Herrero, A. Gotchev, I. Christov, K. Egiazarian, "Feature extraction for heartbeat classification using independent component analysis and matching pursuits," Preceedings of ICCASP2005, Yogyakarta, 2005.

[3] M.B. Tayell, M.E. Bouridy,"ECG images classification using feature based on wavelet transformation and neural network," Proceedings of AIML 06, Sharm El Shekh, Egypt, Alexandria University, Egypt, 2006.

[4] S. Karim, P. Kabo, EKG dan Penunjang Beberapa Penyakit Jantung untuk Dokter Umum, FKUI, 1996.

[5] Meurs-Arntzenius,Elektrokardiografi Praktis, Penerbit Hipokrates, 1990.

[6] S. Wijaya,EKG Praktis, Binarupa Aksara, Jakarta, 1990.

[7] S. Salivahanan, A. Vallavaraj, Gnanapriya,Digital Signal Processing, McGraw-Hill, Singapore, 2001.

[8] J.S. Walker, Wavelet and Their Scientific Applications, CRC Press, Boston University, Boston, 1999.

[9] S.T. Welstead,Neural Network and Fuzzy Logic Aplications in C/C++, John Wiley \& Sons Inc, 1994.

[10] L. Fausett,Fundamental of Neural Networks, Prentice Hall Englewood, 1994.

[11] S.A. Jones, ECG Notes, F.A. Davis Company, Philadelphia, 2005

[12] K. Shibata, Y. Ikeda, "Effect of number hidden neurons on learning in Large Scale Layered Neural Network," Proceedings of ICROS-SICE International Joint Conference, Fukouka International Congress Center, Japan, 2009. 